University of St. Thomas, Minnesota

UST Research Online

2015

\title{
A Family Affair - Teaching Families Versus Individuals: Insights Gained from 24 Years of Family Business Education
}

\author{
Ritch Sorenson \\ University of St.Thomas, Minnesota, Sore2891@stthomas.edu \\ Jackie Milbrandt \\ University of St. Thomas, jackiemilbrandt@stthomas.edu
}

Follow this and additional works at: https://ir.stthomas.edu/ocbentrpub

Part of the Entrepreneurial and Small Business Operations Commons

This Article is brought to you for free and open access by the Entrepreneurship at UST Research Online. It has been accepted for inclusion in Entrepreneurship Faculty Publications by an authorized administrator of UST Research Online. For more information, please contact asle4660@stthomas.edu. 


\title{
A Family Affair-Teaching Families Versus Individuals: Insights Gained From 24 Years of Family Business Education
}

\author{
RITCH L. SORENSON \\ JACKIE M. MILBRANDT \\ University of St. Thomas
}

Typically, family business owners have a serious purpose for taking formily business classes: They are preparing a new generation to become owners and leaders in their family's business. In the early 1980s, traditional management education (geared toward nonfamily business management) left a critical gap in family business education. Mainstream management programs at that time did not include content specific to formily businesses (Sharma, Hoy, Astrachan, \& Koiranen, 2007). Although a growing number of universities today offer family business classes, most are still set up to teach individual learners, not families (De Massis \& Kotlar, this issue; Sharma, et al., 2007; Steier \& Ward, 2006). Similar to scholars who advanced the need for family business education (Sharma et al., 2007), we advance the need here for transgenerational business family learning as a next step in the evolution of family business education.

We explore the relationship between communities of practice (CoP) and learning communities (LCs) in family business. We do this through a longitudinal examination of the development of family business education at the University of St. Thomas, Minnesota (UST). This case study traces the history of how "champions of change" led to the formation of a "community of practice" at UST; which in turn, facilitated the development of the current business fomily "learning communities"

We would like to thank and acknowledge the coeditors of this special issue for their valuable and insightful comments in developing this paper. Most especially, we thank Mike Wright for his support and guidance. found at UST today. Our work here focuses on three reseorch questions:

1. "What are the characteristics of UST's community of practice, and how does the community of practice contribute to developing business fomily education?"

2. "What conditions enabled UST to establish learning communities within and among business fomilies?" and,

3. "What perceptions are held by the business families who have participated in classes designed as learning communities?"

To answer these questions we collected data from multiple sources. We reviewed relevant historic documents (e.g., past course syllabi) and management education literature, and we interviewed former students and family members who participated in our classes. Our study reports the findings and insights gained from our case review.

First we summarize the process UST used to develop a community of practice in family business and how the CoP continues to influence program development. Second we identify key conditions and outcomes we associate with a business family learning community. We include details about the process used at UST to develop learning communities as well as an overview of content of the current foundation class, Family Business Ownership. We then summarize the methods and findings of interview research we conducted to assess the student experience of the class, and conclude with a general discussion about how other universities might adopt or adapt the approaches presented in this case study to develop business family learning communities elsewhere. Before proceeding with the body of the paper, we define 
and describe communities of practice and learning communities.

\section{COMMUNITIES OF PRACTICE AND LEARNING COMMUNITIES}

The terms communities of practice and communities of learning are often used interchangeably (Lave \& Wenger, 1991; Wenger, McDermott, \& Snyder, 2002). However, we use "community of practice" to refer to key stakeholder groups (university, family businesses, and advisors/practitioners) and "learning community" to refer to regular interactions within and across business families. Below, we define communities of practice and learning communities.

Communities of practice (CoP) are defined in the literature as a group of people who share similar concerns, problems, and interests, and work together to deepen knowledge and expertise (see, Lave \& Wenger, 1991; Wenger et al., 2002). Lave and Wenger (1991) further describe this work as situated learning -in which both senior and junior members of a community engage in developing and transferring knowledge in ways that critically impact community development (Armstrong \& Mahmud, 2008; Houde, 2007; Zhu, 2009). Recent management literature has expressed a growing interest in this type of collaborative and holistic mode of learning (Armstrong \& Mahmud, 2008; De Déa Roglio \& Light, 2009; Hoover, Giambatista, Sorenson, \& Bommer, 2010; Zhu, 2009).

Learning communities (LCs) are defined in the literature as multimember groups whose frequent interactions lead to the transfer and development of new knowledge or professional practices (Marsick, Bitterman, \& Van der Veen, 2000). Sometimes defined as a cohort model (Dodge \& Kendell, 2004), the knowledge creation and development process used in LCs are often described as discursive (Brown \& Duguid, 1991; Bitterman, 2000) and iterative. As members learn about new concepts, they share prior experiences that can help them to develop new ways of knowing, acting, and being. Therefore an essential benefit of a learning community is that the knowledge it develops can readily be applied as capital to group and individual processes (Kearney \& Zuber-Skerritt, 2012; Wenger et al., 2002). Our work contributes to the current dialogue in management education through an in-depth exploration of the impact CoP and LCs may offer transgenerational family businesses.

\section{Influences of a Community of Practice in Establishing Business Family LCs}

In this section we identify the major influencers (i.e., key stakeholders) and influences (i.e., events) that informed the development and design of family business education at UST. We review the relationships that were built and maintained in forming a community of practice, as well as the characteristics and activities that continue to influence UST's business family learning communities. Using historic artifacts (syllabi and documents related to the landmark course) and significant recent events (conferences and publications), we examine UST's community of practice and its role as a "champion" of formily business.

\section{Key Stakeholders Groups}

As stated above, a community of practice is a group of people who share a common interest and work together to develop shared knowledge. At UST, the CoP consists of three stakeholder groups:

1. The university (administrators, faculty, and staff);

2. family business owners (current and potential family business owners); and,

3. advisors (family business practitioners, business experts, and consultants).

The university provides CoP sponsorship, administrative and staff support, faculty, and education expertise. Key stakeholders within the university who support and sponsor family business learning communities are the center directors and staff who provide the infrastructure for bringing together and maintaining relationships among the greater stakeholder community. Fomily business owners provide financial resources, generate support within the larger community, and provide insights about effective business family education. And advisors contribute insights and expertise gained from experience educating and developing many business families.

Initially, stakeholder groups came together based on the expressed need of the "champions" of family business education. In the early 1990s, two highly influential and engaged stakeholders at UST, both family business owners, were attending weekend seminars at another university. They found that more than any other approach, learning together as a family had helped prepare their business families for ownership and leadership transitions. They approached university leaders about developing similar education programs at UST, and provided 
an endowment that enabled UST to hire an endowed chair in formily business.

Over the years, UST has learned from experience the importance of an infrastructure to sustain the CoP. The initial endowed chairperson maintained the CoP by himself with guidance from a board of advisors-a heavy load that left little time for research. When he left and the current endowed chairperson (and Academic Director for the Family Business Center) was hired, an additional endowment from family business owners enabled UST to hire a Family Business Center Director and staff. These individuals worked together to reestablish the CoP. To provide governance for family business programming, they developed a new board of advisors that included family business owners and advisors. And, they worked to establish relationships within the formily business community.

\section{Family Member Involvement}

From the beginning, the CoP promoted educating not only the student, but formily members who worked in the family business. Instead of adopting the traditional university model of educating individual students, an additional fomily member (parents or significant relatives) was required to attend the class. This was explicit in the original course syllabus that stated:

Students should invite a parent or other significant relative from the family business to attend and participate in the course. Our experience has demonstrated that formilies participating in this course report improved family learning and development.

This policy set UST on the unique path of "family learning and development" versus individualstudent learning and development. The policy remains central to the family business course today-parents or other significant relatives are expected to attend and participate with the expectation that family learning and development will occur.

\section{Key Events That Led to a Multifamily Member Approach}

In 2007, when a new endowed chairperson and academic director was hired, the first effort made was to reinvigorate the CoP by recruiting family business scholars, owners, and advisors to help develop new content for the family business course. Representatives of the CoP were invited to participate in three "structured dialogue conferences" between 2008 and 2010.

Each conference focused on different cutting edge concepts in fomily business: family capital (see Sorenson \& Bierman, 2009); formily social capital (see Sorenson, 2011); and the landscape of family business (see Sorenson, Yu, Brigham, \& Lumpkin, 2013). The CoP helped to further define and find applications for these concepts. Each conference consisted of three 2-hour sessions in which brief presentations were given followed by structured dialogue-brief comments taken in order so everyone could participate (see Sorenson, 2011). In a fourth and final session of each conference, the participants summarized possible applications for family businesses. Below, we provide a brief overview of each conference, after which we summarize how concepts from the conferences influenced course design.

\section{Family Capital Conference}

The first conference held in 2008 was based on an award-winning dissertation (Hoelscher, 2002) and an article about family capital (Hoffman, Hoelscher \& Sorenson, 2006). Sponsored by UST"s Family Business Center, key stakeholder groups in the CoP (business owners, advisors, and university faculty members) were invited to attend. Selected scholars presented new research related to the concept of family capital, which was defined as social, human, and financial resources available within an owning family (see Sorenson \& Bierman, 2009; Danes, Stafford, Haynes, \& Amarapurkar, 2009). In each of three sessions scholars provided brief presentations, based on papers they had written earlier, followed by facilitated dialogue among participants. After the conference, scholars incorporated relevant feedback from the conference into their papers. These were published in a special issue of Family Business Review. One conclusion from this conference was that family capital offered a potential competitive advantage to family business owners (Danes et al., 2009; Eddleston, 201l; Sorenson, Goodpaster, Hedberg, \& Yu, 2009) and to new ventures (Chang et al., 2009). An important outcome of the conference was the realization that social capital is fundamental to maintaining family capital. Without family social capital, family members may not willingly contribute their human resources; 
therefore, our CoP sponsored another conference that focused on family social capital.

\section{Family Social Capital Conference}

In 2009, a second structured dialogue conference on family social capital convened at UST. Family social capital is defined as "trusting, cooperative relationships that enable collective action" (Sorenson, 2011: 1). Because practitioners had difficulty relating to scholar presentations in the previous conference, owners and advisors were invited to join scholars in presenting papers. Papers presented at the conference were revised to incorporate what was learned about social capital and then published in a book that also includes summaries of conference dialogues (Sorenson, 2011). A major theme of the conference was that social capital needs to be cultivated in the business family. In the final session of the conference, participants summarized how social capital might be developed and sustained:

- Engage in positive, open, and inclusive communication.

- Develop and celebrate an identity that unifies family members across generations.

- Collaborate about, rather than impose values.

- Organize and learn to work together.

- Recognize that investing in social capital enhances human and financial capital (Sorenson, 2011: 227-228).

\section{Landscape of Family Business Conference}

In 2010, a third structured dialogue conference was convened that also engaged CoP stakeholders.
Business owners and advisors joined scholars in conversations regarding presentations about the Londscope of Family Business (Sorenson, Yu, Brigham, \& Lumpkin, 2013). The presentations briefly summarized the seven themes that emerged from cluster analyses of 257 empirical studies on family business, extrapolated from 12 years of published research (see Yu, Lumpkin, Sorenson, \& Brigham, 2012 for a full description).

In addition to the presentations on major themes, a visual summary of the research, was presented. Following the conference, $\alpha$ third-generation owner of a family business attending the conference volunteered to plot the major governance activities of his family business onto the landscape, demonstrating that the research had meaningful applications for formily business owners (see Sorenson et al., 2013: 210). Currently, we use the Simplified Landscape of Family Business (see Figure 1) to visualize the governance processes business owners might develop to obtain long- and short-term objectives for the business and the family.

Thus, we have consistently relied on the CoP as a guide for family business programs. Currently, family business owners and advisors join university professors and administrators on our board of advisors, and input from the CoP informs our understanding of how we can best help transgenerational business families and keep programming relevant.

\section{Summary and Applications}

The knowledge developed in our three CoP conferences influenced us to move from inviting one

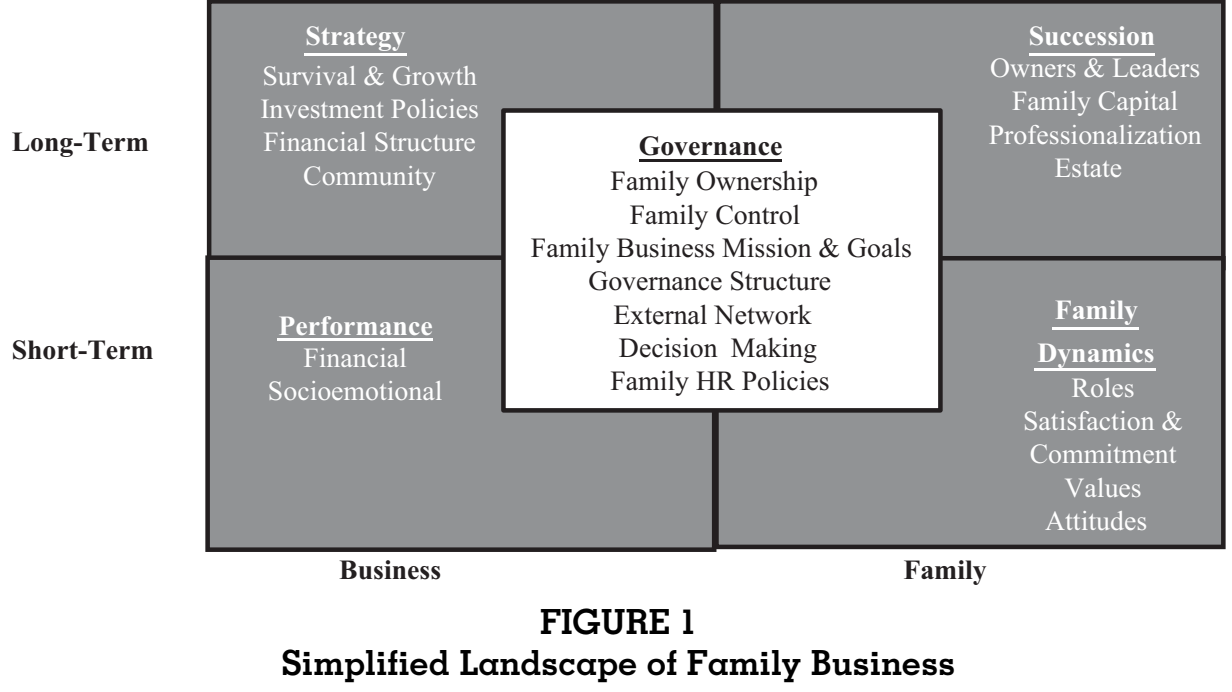


family member to attend class to inviting all members of the business family (owners and prospective owners). The rationale came from the concepts and applications developed in the three conferences.

Family capital consists of resources within the family that can be made available for family business purposes. When the entire business formily attends class, they are in a better position to explore resources available in the family and incorporate them to accomplish business family objectives. For example, when one formily explored family-member skills, abilities, and aptitudes during a family meeting, the family found that stay-at-home moms had organizational and communication skills that were underutilized. During the great recession, those abilities became valuable resources that helped save the formily business.

Social capital consists of cooperative, trusting relationships that enable the business family to work together toward common goals. Social capital is the "glue" that sustains relationships. It provides the foundation for family-member willingness to contribute their human resources for business fomily purposes. When the entire business family participates in class, they more readily strengthen family social capital.

The landscape of family business defines the family business territory. The entire territory includes the business and the family (see Figure 1). When the business fomily can visualize "their" family business landscape, establish short- and long-term objectives for business and family, and establish governance mechanisms to pursue those objectives, they can call upon human, social, and financial capital within the family to accomplish objectives. The Simplified Landscape of Family Business (referred to in the remainder of the paper as the Landscape Map) provides a framework that helps the business family to plan and organize.

As a result of meeting in three conferences with representatives of our $\mathrm{CoP}$, it became apparent that the next step forward in family business education was to encourage all business family members to attend the family business course (Steier \& Ward, 2006). The importance of developing learning communities within and between business families also became apparent.

\section{BUSINESS FAMILY LEARNING COMMUNITIES}

In general, educators are concerned about making classroom learning relevant and meaningful. Educators accomplish this when students can apply concepts to a situation or context (e.g., Zhu \& Bargiela-Chiappini, 2013). Some instructors find creative ways to bring context into the classroom (e.g., Houde, 2007). In our business family learning communities, each family group brings its unique family business context into the classroom. While learning communities share many similarities with CoP (Dodge \& Kendell, 2004; Lave \& Wenger, 1991; Marsick, Bitterman, \& Van der Veen, 2000), we differentiate them by defining a LC as cooperative learning that happens within and among business families. We find that the foundation for establishing LCs within and among families is creating "learning spaces" (see Kolb \& Kolb, 2005).

\section{Business Family Learning Spaces}

Learning spaces occur when classroom conditions encourage individuals to drop barriers and openly share feelings, thoughts, and experiences (Kolb \& Kolb, 2005; Nonaka \& Konno, 1998). Learning spaces enable the business family to engage in experiential learning by openly sharing experiences and collaborating to apply course concepts (Kolb \& Kolb, 2005).

Several conditions help to establish a learning space: (1) There must be a sense of trust and psychological safety within the LC. One way we do this is by asking participants to sign a confidentiality agreement stating that they will not identify the families who share personal experiences in class. (2) There must be regular interaction among group members. One way we help business families develop new interaction norms is through regular business family communication in class and assigning them to have meetings between classes. (3) There must be respect and a shared seriousness of purpose within the LC (Kolb \& Kolb, 2005; Nonaka \& Konno, 1998; Wang, Lin, Li, \& Lin, 2014).

If any of the conditions described above do not exist, we have found the learning space is compromised. For example, in one family business class, we were constrained to admit many students who were not from a family business. Even though participants signed confidentiality agreements, students from nonfamily businesses did not have the same serious intent to learn, which resulted in business family members not having enough psychological safety to openly share their experiences. The trust required to develop a learning space did not develop and, compared with other family business classes, very little experiential learning occurred. 
Finally, trust is built when individuals have a longterm commitment to the community (Wong et al., 2014). This commitment is demonstrated by consistent attendance in classes. Over time, business families become more open and willing to share experiences. Since we began following the guidelines provided above, more experiences are shared, resulting in greater learning and increased interest in participating within learning communities. When a learning community is established and experiential learning occurs, the level of applicable learning for exceeds the traditional university individualstudent learning model.

\section{Levels of Experiential Learning}

Over the years, variations of engagement and experiential learning have been observed within our classroom LCs. Below we offer our observations and summarize the characteristics that limit or contribute to experiential learning.

Kolb \& Kolb (2005) describe experiential learning as a holistic, recursive, and interactive process that creates new knowledge and that begins with experience. In the case of our business family LCs, we call upon business families to use prior as well as new experiences to enhance their learning. As we introduce new concepts, we encourage business families to reflect on how those concepts relate to their personal experience. Then we ask individuals to share and discuss experiences with one another. As members in the LC share experiences, new conceptualizations and insights develop. Because the process is recursive, we encourage and facilitate active communication in class and assign activities outside of class to apply what is being learned.

A limitation of using an experiential learning model for business families is that it is processdriven. It takes time. The urgency of managing short-term day-to-day operations can prevent business families from taking the time to engage in the process. For example, most families do not take time for governance conversations associated with long-term planning, such as discussions about owner and leadership succession. Our classes enable business families to step away from the pressure of daily business operations, reflect, and engage in experience-based governance conversations.

Experiential learning becomes very important when planning for succession of family business ownership and leadership. Since succession tronsitions occur only once in each generation, business families often have very little experience from which to draw in planning the next succession. Experiential learning is accelerated when business families engage in peer discussions with one another (Lave \& Wenger, 1991). Experiential learning is also accelerated when multiple members learn together in class because each formily member views discussions from a unique perspective, finding applications for their individual roles.

Below, we discuss three levels of experiential learning that correspond with three types of family business classes (see Figure 2). The first type of class is individual-student classes-traditional university model. Often students in these classes may or may not come from family businesses. This type of class provides low experiential learning. The second type of class is one in which one family member attends class with the student, which provides moderate experiential learning. In third type of class students attend with their business families, which provides high experiential learning.

\section{Individual-Student Classes: Low Experiential Learning}

The traditional university model is teaching individual students. These classes use case examples to provide the context for application of course concepts. Students from family business are similar to working adults who are enrolled in executive education classes. Their experience in the family business provides a context for application of course concepts. Frequently, however, students have limited experience in their family's business, making it difficult to apply course concepts. If more experienced family members are readily available to the student in class, they can fill in students' gaps of knowledge about the family business.

We find that even when students from family businesses attend class without family members present, they are interested in course content. And, when given the kinds of assignments described in Table l, they can find meaningful applications. However, one of the authors taught at a public university before coming to UST. That university used the traditional individual-student model. The university regularly admitted students who are not from fomily businesses. Such students did not have the context for application of course concepts (Lave \& Wenger, 1991). So, similar to other business courses, cases and clips from movies were used to 


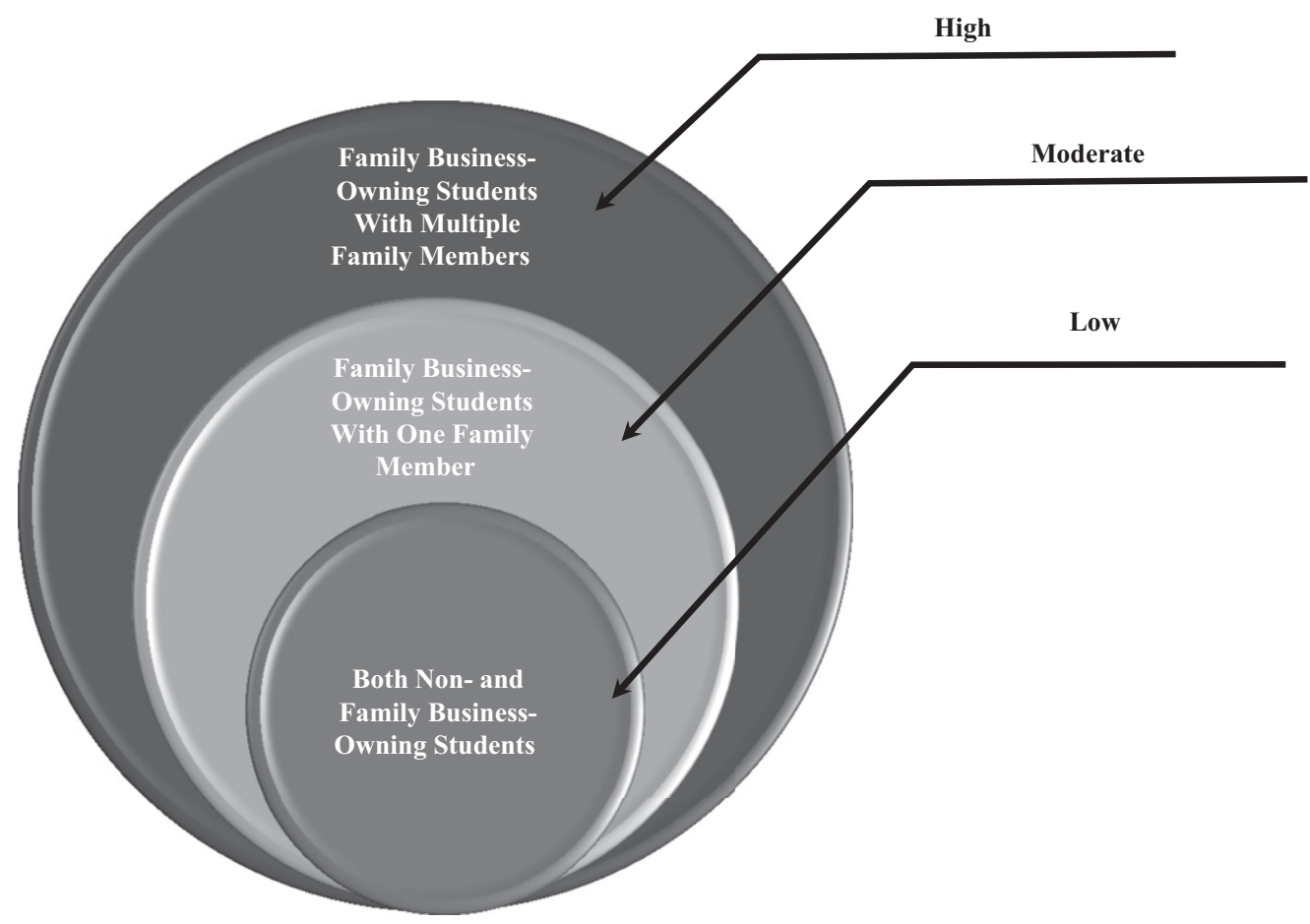

FIGURE 2

Levels of Experiential Learning

provide a context. Unfortunately, nonfamily business students often did not have serious intentions to learn (Wang et al., 2014). The level of engagement and level of experiential learning in those classes was very low.

A similar experience occurred at UST. After having taught classes for several years with family members attending with students, we yielded to UST enrollment pressures and scheduled a class during the daytime for students without the requirement of family-member participation. The majority of students admitted to class were not from family businesses. Their lack of a serious intent or purpose combined with a lack of relevant context to apply knowledge resulted in a failure to apply course content. Even when cases and family business speakers helped to provide a context, students who were not from family businesses engaged little in class discussions. And, feeling a lack of a safe learning space, students who were from formily businesses withheld sharing their experiences (Wang et al., 2014). Topics and issues that had stimulated much discussion among business families in other classes failed to promote discussion in this one.

The result was that students from family businesses did not have the rich learning experience and the opportunity for family development that they could have had. Without family members present, we could not engage in interaction activities that help develop family capital and family social capital, as will be described below. And, although the students initially found the Landscape Map interesting (see Figure 1), they did not appreciate its multiple applications and quickly lost interest.

\section{Student Plus a Single Family Member Classes: Moderate Experiential Learning}

For this class, students are required to have at least one family member attend with them or to share course content with families between classes and engage them in discussion to help complete assignments. Using a seminar style, the class is scheduled to meet once a week during the evening to enable family members to attend.

Much experiential learning occurs in this class. After concepts are presented, meaningful application discussions occur within and between business families. Often, to discuss concepts and share experiences, the class is subdivided into owner and next-generation groups. Comments are summarized 
TABLE 1

Summary of Course Design Across Time

\begin{tabular}{|c|c|c|}
\hline $1991-2007$ & 2008-2010 & $2011-2014$ \\
\hline \multicolumn{3}{|c|}{ Structure } \\
\hline & Assignments \& course content & \\
\hline
\end{tabular}

Class discussion based on six short paper assignments on following topics:

1. Family Business History: Founder values, culture, main events.

2. Family Participation: Relationships, core values, communication style, conflict management.

3. Management Development: Ownership participation in the business.

4. Ownership and Estate: Family ownership transition planning (e.g., contingency planning, buy/sell agreements).

5. Life/Career Plan: Prepare student for the succession process.

6. Strategic Business Plan: Interdependence between formily and business (parallel planning).
Students selected one of the following topics for a course capstone paper:

1. Career Development: Explore the possibility of joining the family business.

2. Succession: Work with formily to explore succession possibilities.

3. Family Business Continuity: Use system planning to develop family business values, vision and mission, and owner governance structures.

4. Ownership: Family commitment to ownership, ownership structure, and owner governance.

5. Business Strategy: Work with student to clarify strategy for the family business.

6. New Business: Develop a feasibility plan for a new venture.
SECTION I (Students with one family member): Focus on learning through six short student papers.

1. Our Family Business: History, business service/product and model, performance.

2. Family Business Ownership: Current and future ownership; responsibilities of ownership.

3. Values, Vision, Mission, and Goals: Owningfamily values, vision, mission, and goals.

4. Family Capital: Human, social, and financial capital in the business family. Possibilities of using human capital for business or family.

5. Decision-Making: Approach to decisionmaking, including processes (e.g., meeting structure, communication).

6. Governance Structure: Develop governance structure. Calendar, organize and plan governance meetings to form owner agreements and to accomplish business and family goals.

SECTION II (Students with family): Focus on whole family learning through assessment, discussion, and application.

1. Family Decision Making: Assess roles, communication, and decision making. Discuss structure and process for owner meetings. Establish pattern of family meetings.

2. Family Capital and Family Social Capital: Identify individual human capital that can be a resource to business and fomily. Agree on owning-farmily values, mission, and goals. Frequent formily interaction builds social copital.

3. Ownership Agreements: Based on family values, mission, and goals developed from family Landscape of Family Business, develop owner agreements, including ownership and owner responsibilities.

4. Governance Structure: Develop governance structure. Calendar, organize, and plan governance meetings to accomplish business and family goals. 
on flipcharts to share with the class. Contrasts between generations regarding concerns about succession, for example, provide stimulating thoughts and discussions. In addition, students are assigned papers and presentations (see Table 1, details provided under Section I) that require family input outside of class. Class presentations provide a venue for business families to learn from one another. Thus, the class is structured to promote discussion and experiential learning. For students, much of the learning is about their own formily business.

In general, there is a gap in the family business literature in describing how family business owners make governance decisions (De Massis \& Kotler, this issue). The core purpose of this class is to provide experiential learning within a LC that enables transgenerational business families to develop their approach to family business governance, an approach that can achieve the owners' objectives for business and family. Most business families do not consciously discuss their approach to governance or formally consider how governance will change in the next generation. Families recognize that governance in small-to-medium size businesses is not the same as it is in large public corporations. For example, most family businesses do not have formal, independent boards of directors (see Sorenson, 2013, for a brief review) to help guide their ownership decisions. Additionally, the business family must govern to not only obtain business, but also family outcomes. So, a fundamental part of our "business family" learning approach is designed to help transgenerational owners develop governance strategies and agreements adapted to their particular family business needs. Discussions within and among business families enable these business families to learn from one another in developing their approach to governance.

Our approach is to define and describe the elements of governance included in The Landscape Map (see Figure 1) and then have each business family determine how each element is defined and applied. Early on, we have business families determine who can become family owners (e.g., must you work in the business to be on owner?) and how they will maintain ownership control (e.g., percentage of shares retained in the family, voting shares, and responsibilities of owners). The LC helps business families acknowledge that they prefer to keep ownership and control in the family (e.g., Bammens, Voordeckers, \& van Gils, 2011; Uhlaner, 2013) and determine how they will do that.
In addition, we have business families consider how they will engage in ownership decisionmaking (see Figure 1). We help families consider acceptable structures, communication norms, and decision processes for decision-making (Sorenson, 1999). We assess group decision-making and conflict practices using a measure adapted from Rahim (1983) and have business families consider ways they can improve. We also encourage business families to discuss ways to improve meeting processes before concluding meetings.

We assign families to have at least one meeting a month during the semester. An outcome of this class is that regular family meetings almost always become a vehicle for making decisions. And, we encourage business families to schedule regular meetings for information and decision-making purposes (Sorenson, 1999; see also Basco \& Rodríguez, 2009).

Core decisions business families make during class are family human resources policies (e.g., requirements for family ownership and working in the business). And, we ask business families to develop a list of governance and human resources decisions they will make in the future.

Business families also consider governance structures (see Figure 1) appropriate for their family business. In addition to forming a family council or assembly for family governance, business families determine whether they will have a formal board of directors, a board of advisors, or other unique structures to meet owning family and business needs (e.g., Bartholomeusz \& Tanewski, 2006; Martin-Reyna \& Duran-Encalada, 2012). Some formilies, for example, have representatives of each family branch sit on a family business board, which obtains input from a professional advisory board. If their goal is to grow the business, families may desire to develop on independent fiduciary board. In addition, we help business families formalize governance by calendaring, staffing, and planning business and family governance meetings.

Early in the class, we focus on family business mission and goals (see Figure 1). We provide several exercises to help the business fomily agree on short- and long-term goals for the business and the family. We begin by having the business family agree on core values. Each individual selects top values from Rokeach's list of values (1973) and values we have culled from other family businesses. Then based on these values, the business family develops its mission and goals. When the business family understands their mission and 
goals for business and family, they can support one another in achieving them (see quadrants in Figure l, also Alavi \& Karami, 2009; Basco \& Rodríguez, 2009; Nam \& Herbert, 1999).

Finally, we encourage business families to extend their external network beyond the business families in our class (see Figure 1). Multiple members of the business family can develop external networks, extensively broadening network resources. One valuable network resource can be family members who do not work in the business (see Anderson, Jack, \& Dodd, 2005). Other resources can include legal and financial professionals, industry associates, the business community, and government representatives (e.g., Fiegener, 2010; Perry \& Ring, 2013). Often, business formilies share important network contacts with one another during class.

Because we expect the business family to be involved in our class, we engage the family in activities that reveal family capital (human, social, and financial capital; Danes et al., 2009; Sorenson \& Bierman, 2009). We ask family members, even those who do not attend class, to engage in a series of selfassessment exercises to help them identify individual human resources that could help the family obtain business and family goals.

Family social capital is also developed in the class (Salvato \& Melin, 2008; Sorenson, 2011). One of the ways we encourage developing social capital is through teaching collaborative communication skills (see Hubler, 2009; Miller, Nunnally, Wackman, 1975; Miller \& Miller, 2003). Frequent meetings inside and outside class strengthen family capital, as does agreeing on family values, mission, and goals.

Together, LC interactions and activities enhance understanding of family human capital and change the way families communicate to strengthen social capital. In-class discussions strengthen the relationships of the student and the family members who attend class. Interactions with family members necessary to complete assignments help to strengthen relationships among family members. Monthly meetings also increase communication and alter the family's approach to communication and decision-making.

Some students' families live too for away to attend class. To fulfill class requirements, these students agree to call or Skype family members to share and discuss course content. These students have the task of learning new concepts, identifying what they think is important, and teaching those concepts to the family. Unfortunately, the student may overlook information that may be important to some family members. So, we encourage students to take detailed notes of presentations and class discussions to share. We also encourage them to share handouts and PowerPoint slides.

\section{Students Plus the Business Family: High Experiential Learning}

These classes are very similar to the class described above for students and one family member; however, they are designed for all owners and prospective owners to participate in day-long seminars that meet four times during the semester. To meet academic requirements, students meet with the instructor between seminars to engage in peer discussions, further analyze their families' businesses, and deliver presentations about course concepts.

\section{"These students have the task of learning new concepts, identifying what they think is important, and teaching those concepts to the family."}

Having all members of the business family in class makes business family learning more efficient and effective. When they learn together, all business formily members are exposed to the some concepts, and they can reflect on and conceptualize potential applications together, enriching family learning (Houde, 2007; Steier \& Ward, 2006; Wenger et al., 2002). For example, when introduced to the ThreeCircle Model (see Tagiuri \& Davis, 1996), Family Business Orientation (fomily-first, business-first, etc., see Ward, 1987; Basco \& Rodríguez, 2009), and the Landscape Map (see Figure 1; Sorenson et al., 2013; Yu et al., 2012), business families con quickly discuss those concepts in relation to themselves and their businesses. They acquire new language simultaneously, and they can quickly develop business family and position-based applications. For example, leadership concepts may have different applications for senior leaders, next-generation leaders, and spouses who help develop future leaders.

Including the whole business formily also builds family social capital. Aside from family dinners, most families hold few family meetings. By the end of the course, our business families have engaged in 18-22 business formily meetings. In addition to inclass meetings, these business families are assigned to hold two meetings between monthly seminars. By the end of the course, the business family has 
changed the way they communicate and have established new meeting habits. We find that most families continue holding formily decision meetings long after they finish our course.

Moreover, when the business family attends class, very high levels of experiential learning occur (Nonaka \& Konno, 1998). Business families communicate with one another. Individuals in similar positions learn from one another. For example, spouses who do not work in the business compare their roles in supporting the business. Each person learns from the experiences of the others, shortening experiential-learning cycles, thus, fomily dynamics can change toward collaborative decision-making.

However, the high communication, high collaboration approach of an experiential-learning class is not for everyone. For some business formilies, especially those with paternalistic cultures characterized by autocratic decision-making, collaborative communication may not be a good fit (Dyer, 1988; Birdthistle \& Garavan, 2013). So, we make efforts to clearly describe the differences between sections, enabling students and fomily members to enroll in the section that best with fits their family norms and circumstances.

In summary, the courses that invite formily member attendance are designed to (1) find applications for core formily business concepts, (2) reveal family capital, (3) develop family social capital, and (4) promote owning-family governance and collaborative decision-making. Since we have adopted the business family approach, we have seen our class sizes increase as more family members attend with enrolled students. The average number of formily members attending class has nearly doubled (see Table 2).

\section{ASSESSMENT OF THE STUDENT PLUS FAMILY CLASSES}

To assess the effects of our learning community approach, we conducted a study to determine the reaction of business families. We sought to determine the impact of our attempts to develop learning spaces and experiential learning within and among business families. To objectively assess business family reactions, we arranged for Family Business Center staff to conduct interviews with students and their formilies.

\section{Research Method}

Our sample was taken from families that had attended class with one or more family members between 2010 and 2013. The sample represented $15 \%$ of attendees. We interviewed multiple family members from seven families. Two families had only one family member in class with the student. The remainder had multiple family members attend (see Table 2). All families had retained some level of connection with our Family Business Center.

We interviewed at least two family participants representing each generation from each family group. Our sample represented a diverse population of transgenerational businesses (i.e., founder to next-generation siblings and siblings to cousin consortium) as well as diversity in type and size of businesses. We developed a short interview protocol asking participants to comment about their experience in the class. After conducting all the interviews, we used a structural coding method to process the interview data, and grouped the interview responses into categories. Then we looked for themes that emerged in responses (e.g., Saldaña, 2013; Auerbach \& Silverstein, 2003). Below, we summarize what we learned from these interviews and then discuss implications for future research.

\section{Common Themes}

Five common themes emerged from formily member comments (see Table 2, Summary of Themes and Study Participants for a summary of comments each family group made related to each theme):

- family learning together,

- classroom learning community,

- relevance,

- core concepts and assessments, and

- family meetings.

Below we offer a brief discussion about each theme and examples of quotations we used in defining the themes.

\section{Family Learning Together}

In our interviews, we found a common attraction of the class was that families enjoyed spending time together away from work. One next-generation family member commented that the experience was a "unique and fun environment to learn together. Outside of workplace, but connected by the work ..." Another family owner commented, "The content was good, but just being together was really good. Forced us to sit down and talk and think. . . there is a lot of value in getting everyone together."

Another family commented on the benefit of having family members together in class, stating, "I 
TABLE 2

Summary of Themes and Study Participants

\section{Themes}

\section{Family learning} together

\section{Classroom learning community}

Relevant context

Core concepts

Family meetings

\section{Summary of Theme-Related Comments}

0 (hearing the same information at the same time), 1 (being together as a family; proud father), 2 (being together so we could talk and learn how to develop constructive communication), 3 (great to learn everything at the same time/shared understanding), 4 (helped to create a peer level in the family owner group/ having everyone hear the same stuff at same time), 5 (all learning the same thing at the same time), 6 (all learning the same thing at the same time).

0 (hearing what other families had done and that what others did and do were pertinent to our family business), l (fellowship; guest speakers, networking with other family businesses), 2 (insights from family business owners/ relate and see what is similar and future challenges), 3 (families had similar issues/ learn new perspectives), 4 (hearing the problems/challenges of others and knowing you're all in the same boat), 5 (stories shared, having multiple generations in the classroom was a real asset/ helped us to address the topics-e.g., policies for in-laws, blood-only owners-we were aware of but avoiding) 6 (the involvement of other family members).

0 (real examples), 1 (content addressed SMEs not corporate-size business, and was tailored to specific FB needs; e.g., succession, credibility, compensation/estate planning), 2 (not able to apply everything but enough to help us begin preparing for the first succession), 3 (how to deal with conflict and disagreements, policies, working with nonfamily employees), 4 (I could apply it everyday life), 5 (we are still integrating, other classes focused on corporate model, this information was easy to transfer to application because it was geared toward SMEs), 6 (It was exactly what we needed at the time, even though we didn't know it). 0 (succession planning, continuity, generational issues), l (basic FB framework, family capital, MBTI, getting over conflicts, succession), 2 (basic FB framework for family business, communication, planning for the future, succession), 3 (MBTI, Strengthsfinder, policies, succession), 4 (mission, vision, value/ SWOT/MBTI over all basic FB framework, professionalizing, succession) 5 (separating family and business, communication, MBIT, succession, expectations, long-term vs. short-term planning), 6 (mission, vision, values, succession planning, family capital, generational issues, long-term vs. short-term).

1 (helps us prepare as a next generation owner-group; builds confidence in next generation having the meetings), 2 (talk together), 3 (having family meetings to work on the business not in it), 4 (still having them), 5 (hard to keep having them, but they continue to try), 6 (worked on communication/still have them).

\begin{tabular}{|c|c|c|c|c|c|c|}
\hline Year attended & $\begin{array}{l}\text { Subject } \\
\text { code }\end{array}$ & Generation & $\begin{array}{c}\text { Number participating } \\
\text { in class }\end{array}$ & $\begin{array}{c}\text { Number formily } \\
\text { members interviewed }\end{array}$ & $\begin{array}{l}\text { Enrolled families } \\
\text { in class }\end{array}$ & $\begin{array}{c}\text { Sample percentage } \\
\text { of population }\end{array}$ \\
\hline 2010 & 6 & $2^{\text {nd }} \& 3^{\text {rd }}$ & 2 & 2 & 10 & $10 \%$ \\
\hline 2011 & 5 & $1^{\text {st }} \& 2^{\text {nd }}$ & 4 & 2 & 5 & $20 \%$ \\
\hline 2012 & 2 & $1^{\text {st }} \& 2^{\text {nd }}$ & 3 & 2 & 6 & $17 \%$ \\
\hline 2012 & 3 & $4^{\text {th }}$ & 5 & 3 & 6 & $17 \%$ \\
\hline Total & & & 26 & 18 & 50 & \\
\hline$M$ & & & 3.71 & 2.57 & 7.14 & $15 \%$ \\
\hline
\end{tabular}

Note. All families were interviewed by phone or in person by a third-party interviewer working with the University of St. Thomas Family Business Center. In each case the participants were asked questions from the same interview guide. Except for data collected from interview 0 , in which responses were submitted in writing, all interviews were recorded and the data were summarized from transcribed notes.

liked that we all heard the same thing at once.... that it wasn't like one of us telling somebody and things getting lost in translation." And another commented:

The real critical piece of you [G1] and I [G2] going to class together.... If I were to have taken the class alone, things get lost in translation ... the fact that we sat in that class together, you [Gl] heard the same things I did. We formulated plans together, I didn't have to translate things.

The process of listening, discussing, and applying develops a "family point of view" (Sorenson 
et al., 2009) that can be used to develop social capital (see Gedajlovic et al., 2013). We have found that when multiple family members hear and discuss the same concepts, they are more likely to apply those concepts.

\section{Classroom Learning Community}

The initial policy to include family members in class has enriched and shaped the nature of classes at UST. Because students are expected to include family members, student enrollment has traditionally been relatively small-on average 10-12 students per class (see Table 2). However, when family members are included in the student count, class sizes are approximately $20-25$ participants. On average, $50 \%$ of the students attend with one other family member-often a parent who heads the business. For about $20 \%$, both parents attend. The remaining $30 \%$ of students attend with multiple family members (e.g., siblings, cousins, aunts, uncles). One participant described the experience:

I think it's interesting that we had different generations. And the class would be divided up into generational groups at times and each group would deal with the same two questions. And when we came back together, boy you could really see the generational gaps. And I think understanding that it's not just "my son," or the "old man" doesn't get it - that was really valuable. ... it totally changed the dynamics of our family.

We also found collaborating enabled next-generation family members (students) to communicate with senior family members more freely, promoting intergenerational learning and acquisition of tacit knowledge about the family and the business (Armstrong \& Mahmud, 2008). Examples of comments participants made include, "From my perspective it put everybody on the same level.... it wasn't [just] senior talking down... all [were] learning, discussing, and throwing things out. It was open communication." And, "I got to hear a lot about how our family business is set up. What some of the decisions were about our governance and succession. And so I actually learned a ton."

To answer questions and concerns raised during class, participants often talk privately after class, indicating a genuine concern and interest in one another. Several participants commented on this benefit: "I think the actual involvement of other family members ... I don't know that I could have gotten that out of book." Another commented:

One of the most valuable things were the families. The families that you met and what you learned from their examples and knowing that you could speak about it in a secure environment was even more valuable than the cases or the lectures.

A third commented,

there was such a variety of people in the class ... not just first generation but second or third, and ... they talked about the struggles they had gone through ... it was a real eye opener ... a big asset.

In addition to comments about the classroom diversity, several commented on the benefit of learning from others, stating, "[I liked] hearing their difficulties, and knowing that you're not the only formily experiencing problems." Another commented:

You can glean a few nuggets from your peers. Human behaviors are kind of a mirror. How do others relate to their families? How am I like that and do I like what I'm seeing? Listening to other families and sharing, you learn about culture things and operational things.

\section{Relevance}

Consistent with adult-learning theory, participants thought the course content was highly relevant (Forrest \& Peterson, 2006; Knowles, Holton, \& Swanson, 2012). Several commented about how the course design increased its relevancy. One founder and current owner commented:

We were anxious to take it to action.... I think taking things from thought to action is critical-If I hadn't been there I don't think we would have integrated it, I think I would have blown it off.

A third-generation future owner stated:

What I learned [was] more relevant when I'm with my fomily because it's specifically geared toward our family and our business. So what I learned is extremely relevant. 
And finally a student compared the course to others she had taken as a business major saying,

Compared to education in other classes without formily ... I learned more because, in other business classes, other case studies were all corporate, and made it a lot more difficult to transfer what I was learning . . . to a small business ... I liked the real world application.

\section{Core Concepts and Assessments}

Family members discussed the importance of using course concepts and self-assessments to define the nature of their business family. Specific concepts that families mentioned included applying the Three-Circle Model (Tagiuri \& Davis, 1996) and defining themselves as business-first, fomily-first, or fomily-enterprise-first fomily businesses (e.g., Basco \& Rodríguez, 2009; Distleberg \& Sorenson, 2009). They also mentioned the Landscape Map (see Figure 1), individual assessments (MBTI; Myers, McCaulley, Quenk, \& Hammer, 1998; and StrengthsFinder; Rath, 2007) and the "appreciation exercise" (feedback to one another about what they appreciate). One family stated:

I think we would have been a totally different company, if at all still here today, without the class. Because of the class, what we learned, our willingness to implement it, really opened our eyes to what we had-we were a family business, and the class helped us see what our resources were as a formily.

Finally, family members mentioned the importance of clarifying values and developing vision, mission, and goals statements.

\section{Family Meetings}

Although few business families held meetings before, after attending the class all former students indicate that they now hold meetings and that meetings were the most valuable takeaway. After being assigned to hold them, families recognized the importance of setting aside time for business family governance meetings. According to one second-generation business owner,
The biggest struggle even today, is that we are so obsessed with our day-to-day operations and our day-to-day meetings that it's really, really difficult for us to step back and take a broader look at everything and look at the big picture.... That [seeing the big picture] has been a huge help to get everyone together and focus on those long-term goals rather than our short-term management meetings.

Another participant noted, "We are having G3, quarterly meetings-where everyone over the age of 16 is invited to come in. And we meet about a topic, but it is also a bit social." Another mentioned how they facilitate the meetings: "Even if it's just [a few of] us, have a formal meeting structure. Follow-your agenda. That way things don't get off [track]." And another mentioned how they planned and scheduled meetings. "Having set meetings. We have gotten off track with it, but we were having family meetings, and committee meetings, and management meetings.... that was really helpful."

Because many are meeting for the first time as an owning family, a common experience is "storming and norming" (Tuckman, 1965). Because of close family relationships, the storming stage often comes quickly and can be intense. One family member indicated that a couple of their early meetings "turned out to be just blowouts...yelling and crying and all sorts of emotions," then followed by stating that once they got through the initial emotions, the meetings became a critical part of sharing and role creation for the next-generation owners. Another family reiterated a similar experience, stating that "for the first two months weekly meetings addressed family issues and norms and were highly emotional." Spouses were invited to attend. These meetings examined family patterns and dynamics. Once they had cleared the air, they developed stronger bonds and better working relationships. The patriarch of the family, for example, said he emerged with a much better relationship with a daughter-in-law.

This early storming stage helps business families identify and "unfreeze" existing fomily norms and relationships (Lewin, 1948; Tuckman, 1965) that tend to be hierarchical (parent-child or dominantsubordinate in the family) before they create new norms based on business and family-council roles. Although these meetings can be intense in the storming stage, none of the families expressed regret in holding them. 


\section{Summary and Implications}

Interestingly, the comments were very similar whether one formily member or multiple family members attended class. The comments indicate that high levels of experiential learning occurred in these business families. They learned within their own family and from the experiences of other business families. Learning communities were also evident in family meetings and communication among families.

"[The] early storming stage helps business families identify and "unfreeze" existing family norms and relationships (Lewin, 1948; Tuckman, 1965) that tend to be hierarchical (parent-child or dominant-subordinate in the family) before they create new norms based on business and family-council roles."

Although this preliminary research identified characteristics that contribute to UST's learning communities, we could learn more about how LCs are developed and sustained. We might gather additional data to answer this question:

R1: To what extent and how are learning communities established in business families?

Furthermore, we did not gather data to compare the impact of different levels of involvement in class-one versus all business formily members; therefore, we might gather further information to address this question:

R2: What differences in family learning occur when students attend classes by themselves, with a parent, or with multiple family members?

Our interviews reveal that learning occurs among business families in class both by observation of other families and through "nuggets" obtained from others' experiences; however, we have not systematically examined different kinds of learning and what is most useful. Thus, research could be designed to address the following:

R3: What practices are most useful in developing strong peer-network LCs? What kinds of learning occur and are most useful among business families?

Given the information we obtained from business family participants in our classes, our approach to business family education does establish learning communities. We hope to learn more about what makes these communities successful.

\section{DISCUSSION}

Below, we provide an overall commentary about the strengths and challenges associated with the learning community approach, provide suggestions for increasing family involvement, and describe alternative course designs.

\section{Strengths and Challenges of Family Involvement}

In preparing comments for this section, we interviewed a former instructor in the class and compared his experience to ours. Common strengths included (1) high levels of family member participation resulted in a dynamic and enjoyable learning environment, and (2) multigenerational attendance in class enriched learning in and outside of the classroom. Due to their experience, parents often ask important questions or make insightful comments that enhance the learning experience for everyone. Because course projects and exercises are about their family business and would be read or viewed by other family members, students put considerable effort into papers and presentations.

Family involvement in the class has some challenges. First, the model is unusual for both instructors and university administrators. Instructors must adapt to working with families and family dynamics. A few domineering or controlling parents have stifled open communication within their families and, therefore, also stifle family learning. For example, owners of a chiropractic business kept their thumb on their son (who was rebellious) during class, making his experience unpleasant. In a different family, a domineering owner of a steel manufacturing business did not trust his very capable son who was completing a master's degree and had several years of experience in his industry. He resisted including the son in implementing governance changes.

Second, administrators are concerned about enrollment. As previously mentioned, class sizes in terms of enrolled university students tend to be small. Due to enrollment pressures, sometimes students who were not part of a family business have been admitted into the course. As indicated earlier, we have found that these students typically have low levels of motivation and 
involvement. In addition, their presence tends to dampen general enthusiasm. So, we strongly encourage instructors who attempt using the family model to develop support among administrators for admitting only students from family businesses.

Finally, some owners have difficulty warming up to an academic setting. For example, one nextgeneration family member admitted that their family didn't complete some family assignments. Attending class and changing family communication patterns are ongoing challenges for these busy, successful, and competent adults. However, we have found when they get accustomed to our class, they become trusting and open to the experience, and they find great benefit in the collaborative and experiential process.

\section{Overcoming Challenges of Family Involvement}

Given our favorable experiences from involving business families in class, we encourage other instructors to find ways to include families. Below we provide some possibilities for including fomilies in learning when parents cannot attend every course with their students. The best-case scenario for involvement is when: (1) students and family members learn the same concepts and collaboratively apply new knowledge to their family and business, (2) students report the insights gained in family discussions back to the class orally or in a short paper, and (3) students share insights gained during class discussions with their business family.

When parents cannot attend class, there are ways course content can be shared with families:

- Lectures. Make lectures and group applications instructions available on-line. After watching videos, fomilies could schedule time to discuss them. Students could create summaries of their family discussions to share in class.

- Presentation slides. Over the years, we have had several students meet with or call families and review PowerPoint slides with them. Students reported much learning results from the experience.

- Multimedia. Video- or audio-recorded lectures could be made available to families on-line.

- Family input on reflection papers. These are short papers that require students to write how course concepts apply to their family business (see Table 1).

- Family assistance with in-depth course projects. In UST classes from 2008 to 2010, students selected a term project related to their family business or proposed an alternative project. The project chosen most frequently was continuity planning (see Carlock \& Ward, 2001).

\section{Alternative Course Designs}

In universities that are unaccustomed to family business education, an instructor might try alternative course designs, such as those found in executive education or blended-class models.

\section{Executive Education Example}

The approach used in one section of USTs fomily business courses was based on an executive education model, making it possible for family members to attend four installments of all-day seminars. We combine student families with families from the community to fill the class and bring in supportive income. We have found the seminarstyle class is enriched when 7-10 fomilies participate together. A more typical type of class schedule could be provided through Executive Education or sponsored by a Family Business Center. For example, an executive education class could meet weekly for 3 hours. At UST, we prefer to sponsor the education through the Family Business Center so we can maintain control of course content and delivery.

\section{Blended Class Example}

Instructors in universities that require large course enrollment may need to include students whose families do not own family businesses. As we indicated previously, we find this type of blended class a challenge. Some strategies we used to overcome this challenge included the following: (l) We taught using the case method-drawing upon written cases and video documentaries to help students gain insight into the dynamics associated with formily businesses. (2) Students from fomily business were asked to develop reflection papers and invite families to help them apply course concepts (for reflection topics, see Table 1). (3) We asked all students to conduct family interviews to gain insights about their family history, common family values, family capital, and tacit family characteristics.

\section{CONCLUSION}

The family business courses at the University of St. Thomas are products of a community of practice 
made up of family business owners, advisors, and university faculty, administrators, and staff. Representatives from these three groups are currently actively involved in our community of practice. Family business owners and advisors serve on our advisory board, give presentations in classes, and provide personal examples of how they have governed and planned for their transgenerational family businesses. In addition, highly engaged business fomilies, practitioners, and scholars have participated in center-sponsored conferences to help develop applied knowledge about family business. The importance of continued support of university administrators cannot be overemphasized. Without the critical support of each of these stakeholder groups, the unique type of family business programs we offer at UST would likely not exist.

The decision to bring the family into the classroom has fundamentally shifted our approach in not only what we teach, but also how we teach it. It has resulted in an emphasis on creating learning spaces and learning communities within and among business families. This difference has been noticed. Today UST's family business programs enjoy a strong network of business families who attend classes, events, and participate actively as a learning community. With succession as a primary driver for attending the seminars and classes, we have seen an encouraging trend. As business families transition to the next generation, current owners who took our seminars as many as 20 years ago return to the classes and events with their next-generation owners. This cycle of family businesses as learning communities is encouraging. It indicates we are doing something right. As scholars, teachers, and practitioners, we continue to look for ways to help transgenerational family businesses grow stronger. Creating business family learning communities is one way to do so.

\section{REFERENCES}

Alavi, M. T., \& Karami, A. 2009. Managers of small and medium enterprises: Mission statement and enhanced organizational performance. Journal of Management Development, 28(6): 555-562.

Anderson, A. A., Jack, S. L., \& Dodd, S. D. 2005. The role of family members in entrepreneurial networks: Beyond the boundaries of the family firm. Family Business Review, 18(2): 135-154.

Armstrong, S. J., \& Mahmud, A. 2008. Experiential learning and acquisition of managerial tacit knowledge. Academy of Management Learning \& Education, 7(2): 189-208.
Auerbach, C. F., \& Silverstein, L. B. 2003. Qualitative data: An introduction to coding and analysis. New York: New York University Press.

Bammens, Y., Voordeckers, W., \& van Gils, A. 2011. Boards of directors in family businesses: A literature review and research agenda. International Journal of Management Reviews, 13: 134-152.

Bartholomeusz, S., \& Tanewski, G. A. 2006. The relationship between family firms and corporate governance. Journal of Small Business Management, 44: 245-267.

Basco, R., \& Rodríguez, M. J. P. 2009. Studying the family enterprise holistically: Evidence for integrated family and business systems. Family Business Review, 22(1): 82-95.

Bitterman, J. 2000. Learning communities. In V.J. Marsick, J. Bitterman, \& R. Van der Veen (Eds.), From the learning organization to learning communities toward a learning society: 21-33. Information Series No. 382. ERIC Clearinghouse on Adult, Career, and Vocational Education. Retrieved from http://files.eric.ed.gov/fulltext/ ED440294.pdf.

Birdthistle, N., \& Garavan, T. 2013. Family firms as learning organizations. In A. Örtenblad (Ed.), Handbook of research on the learning organization: Adaptation and context: 210-226. North Hampton, MA: Edward Elgar.

Brown, J. S., \& Duguid, P. 1991. Organizational learning and communities of practice: Toward a unified view of working, learning and innovation. Organization Science, 2: 40-57.

Carlock, R., \& Ward, J. 2001. Strategic planning for the family business: A parallel planning to unify the family and business. New York, NY: Palgrave Macmillan.

Chang, E. P. C., Memili, E., Chrisman, J. J., Kellermanns, F. W., \& Chua, J. H. 2009. Family social capital, venture preparedness, and start-up decisions: A study of Hispanic entrepreneurs in New England. Family Business Review, 22(3): 279-292.

Danes, S. M., Stafford, K., Haynes, G., \& Amarapurkar, S. S. 2009. Family capital of family firms: Bridging human, social, and financial capital. Family Business Review, 22(3): 199-215.

De Déa Roglio, K., \& Light, G. 2009. Executive MBA program: The development of the reflective executive. Academy of Management Learning \& Education, 8(2): 156-173.

Distleberg, B., \& Sorenson, R. L. 2009. Updating systems concepts in family businesses: A focus on values, resource flows, and adaptability. Family Business Review, 22(1): 65-81.

Dodge, L., \& Kendell, M. E. 2004. Learning communities. College Teaching, 52(4): 150-155.

Dyer, W. G. 1988. Culture and continuity in family firms. Family Business Review, 1: 37-50.

Eddleston, K. 2011. The family as an internal and external resource of the firm: The importance of building family-firm identity. In R. L. Sorenson (Ed.), Family business and social capital: 186-197. North Hampton, MA: Edward Elgar Publishing.

Fiegener, M. K. 2010. Locus of ownership and family involvement in small private firms. Journal of Management Studies, 47(2): 296-391. 
Forrest, S. P., \& Peterson, T. O. 2006. It's called andragogy. Academy of Management Learning \& Education, 5(1): 113-122.

Houde, J. 2007. Analogically situated experiences: Creating insight through novel contexts. Academy of Management Learning \& Education, 6(3): 321-331.

Hubler, T. 2009. The soul of the family business. Family Business Review, 22(3): 254-258.

Gedajlovic, E., Honig, B., Moore, C. B., Poyne, G. T., \& Wright, M. 2013. Social capital and entrepreneurship: A schema and research agenda. Entrepreneurship Theory and Practice, 37(3): 455-478.

Hoelscher, M. L. 2002. The relationship between family capital and family business performance: Collaboration and conflict as moderators. Doctoral Dissertation, Texas Tech University.

Hoffman, J., Hoelscher, M., \& Sorenson, R. L. 2006. Achieving sustained competitive advantage: A family capital theory. Family Business Review, 19(2): 135-145.

Hoover, J. D., Giambatista, R. C., Sorenson, R. L., \& Bommer, W. H. 2010. Assessing the effectiveness of whole person learning pedagogy in skill acquisition. Academy of Management Learning \& Education, 9(2): 192-203.

Kearney, J., \& Zuber-Skerritt, O. 2012. From learning organization to learning community: Sustainability through lifelong learning. The Learning Organization, 19(5): 400413.

Knowles, M. S., Holton, E. F., \& Swanson, R. A. 2012. The adult learner, (7th ed.), New York, NY: Routledge.

Kolb, A. Y., \& Kolb, D. A. 2005. Learning styles and learning spaces: Enhancing experiential learning in higher education. Academy of Management Learning \& Education, 4(2): 193-212.

Lave, J., \& Wenger, E. 1991. Situated learning: Legitimate peripheral participation. New York: Cambridge University Press.

Lewin, K. 1948. Resolving social conflicts; and, field theory in social science. New York: Horper and Row.

Marsick, V. J., Bitterman, J., \& Van der Veen, R. 2000. From the learning organization to learning communities toward a learning society. Information Series No. 382. ERIC Clearinghouse on Adult, Career, and Vocational Education. Retrieved from http://files.eric.ed.gov/fulltext/ED440294.pdf.

Miller, S., Nunnally, E. W., \& Wackman, D. B. 1975. Alive and aware: Improving communication in relationships. Minneapolis, MN: Interpersonal Communication Programs.

Miller, S., \& Miller, P. A. 2003. Collaborative team skills, (6th ed.), Littleton, CO: Interpersonal Communication Programs.

Myers, I. B., McCaulley, M. H., Quenk, N. L., \& Hammer, A. L. 1998. MBTI Manual: $A$ guide to the development and use of the Myers-Briggs Type Indicator, (3rd ed.). Palo Alto: Consulting Psychologist Press.

Nam, Y. H., \& Herbert, J. I. 1999. Characteristics and key success factors in family business: The case of Korean immigrant businesses in metro-Atlanta. Family Business Review, 12: 341-352.
Nonaka, I., \& Konno, N. 1998. The concept of "ba": Building a foundation for knowledge creation. California Management Review, 40(3): 40-54.

Perry, J., \& Ring, J. K. 2013. Who are the most trusted family business advisors? Paper presented at the Annual Conference of the United States Association for Small Business and Entrepreneurship, January, San Francisco.

Rath, T. 2007. Strengths finder 2.0. NY: Gallup Press.

Rahim, A. 1983. A measure of styles of handling interpersonal conflict. Academy of Management Journal, 26(2): 368-376.

Rokeach, M. 1973. The nature of human values, Free Press.

Saldaña, J. 2013. The coding manual for qualitative researchers, (2nd ed.), Thousand Oaks, CA: Sage.

Salvato, C., \& Melin, L. 2008. Creating value across generations in family-controlled business: The role of family social capital. Family Business Review, 21(3): 259-276.

Sharma, P., Hoy, F., Astrachan, J. H., \& Koiranen, M. 2007. The practice driven evolution of family business education. Journal of Business Research, 60(10): 1012-1021.

Sorenson, R. L. 1999. Conflict management strategies used by successful family business. Family Business Review, 13: 183-200.

Sorenson, R. L. 2011. Family business and social capital. North Hampton, Massachusetts: Edward Elgar.

Sorenson, R. L. 2013. Owning family governance within the two dimensions of fomily business. In R.L. Sorenson, A. Yu, K. Brigham, \& G.T. Lumpkin's (Eds.), The landscape of family business: 37-63. North Hampton, MA: Edward Elgar Publishing.

Sorenson, R. L., \& Bierman, L. 2009. Free capital, family business, and free enterprise. Family Business Review, 22(3): 193-195.

Sorenson, R. L., Goodpaster, K. E., Hedberg, P. R., \& Yu, A. 2009. The formily point of view, family social capital, and firm performance: An exploratory test. Family Business Review, 22(3): 239-253.

Sorenson, R. L., Yu, A., Brigham, K., \& Lumpkin, G. T., (Eds.). 2013. The landscape of family business. North Hampton, MA: Edward Elgar Publishing.

Steier, L., \& Ward, J. L. 2006. If theories of family enterprise really do matter, so does change in management education. Entrepreneurship Theory and Practice, 30(6): 887-895.

Tagiuri, R., \& Davis, J. 1996. Bivalent attributes of the family firm. Family Business Review, 9 (2): 199-208. (Reprinted from Bivalent Attributes of the Family Firm, by R. Tagiuri \& J. Davis, 1982, Cambridge, MA: Harvard Business School.).

Tuckman, B. W. 1965. Developmental sequence in small groups. Psychological Bulletin, 65(6): 384-399.

Uhlaner, L. M. 2013. Family business and corporate governance. In M. Wright, D. S. Siegel, K. Keasey, \& I. Filatotchev (Eds.), Oxford handbook of corporate governance: 389-412.

Wang, Y., Lin, H., Li, C., \& Lin, S. 2014. What drives students' knowledge-withholding intention in management education? 
An empirical study in Taiwan. Academy of Management Learning \& Education, 13(4): 547-568.

Ward, J. L. 1987. Keeping the family business healthy: How to plan for continued growth and family leadership. San Francisco, CA: Jossey-Bass.

Wenger, E., McDermott, R., \& Snyder, W. 2002. A guide to managing knowledge: Cultivating communities of practice. Boston, MA: Harvard Business School.

Yu, A., Lumpkin, G. T., Sorenson, R. L., \& Brigham, K. H. 2012. The landscape of family business outcomes: A summary and numerical taxonomy of dependent variables. Family Business Review, 25(1): 33-57.

Zhu, Y. 2009. Philosophical underpinnings for equilibrium of values and implication for management education: A response to Harold Levitt. Academy of Management Learning \& Education, 8(2): 290-296.

Zhu, Y., \& Bargiela-Chiappini, F. 2013. Balancing emic and etic: Situated learning and ethnography of communication in cross-cultural management education. Academy of Management Learning \& Education, 12(3): 380-395.

Ritch L. Sorenson, (PhD, Purdue University) is Opus Endowed Chair in Family Business at the University of St. Thomas in Minneapolis. Current research interests are the following topics in family business: ownership, governance, values, family capital, social capital, decision-making, conflict management, and the landscape of family business.

Jackie Milbrandt holds an MA in education and is completing a doctoral degree in Organization Development and Change at the University of St. Thomas, in Minnesota. Milbrandt's research interests include family business; organizational values, culture, and behavior; organizational learning; and human systems dynamics and change. 